\title{
Intersections. Actes du 35e congrès annuel de la- North American Society for Seventeenth-Century French Literature, Dartmouth College, édités par F. E. Beasley et K. Wine
}

\section{Monica Pavesio}

\section{OpenEdition}

\section{Journals}

Edizione digitale

URL: http://journals.openedition.org/studifrancesi/9202

DOI: $10.4000 /$ studifrancesi.9202

ISSN: 2421-5856

\section{Editore}

Rosenberg \& Sellier

\section{Edizione cartacea}

Data di pubblicazione: 1 juin 2008

Paginazione: 183

ISSN: 0039-2944

\section{Notizia bibliografica digitale}

Monica Pavesio, «Intersections. Actes du 35e congrès annuel de la -North American Society for Seventeenth-Century French Literature, Dartmouth College, édités par F. E. Beasley et K. Wine», Studi Francesi [Online], 154 (LII | I) | 2008, online dal 30 novembre 2015, consultato il 16 janvier 2021. URL: http://journals.openedition.org/studifrancesi/9202 ; DOI: https://doi.org/10.4000/studifrancesi.9202

Questo documento è stato generato automaticamente il 16 janvier 2021.

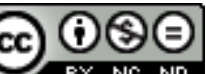

Studi Francesi è distribuita con Licenza Creative Commons Attribuzione - Non commerciale - Non opere derivate 4.0 Internazionale. 


\title{
Intersections. Actes du 35e congrès annuel de la -North American Society for Seventeenth-Century French Literature, Dartmouth College, édités par F. E. Beasley et K. Wine
}

\author{
Monica Pavesio
}

\section{NOTIZIA}

Intersections. Actes du 35e congrès annuel de la -North American Society for Seventeenth-Century French Literature, Dartmouth College, 8-10 mai 2003, édités par F. E. BEASLEY et K. WINE, (Biblio17-161), Tübingen, Gunter Narr Verlag, 2005, pp. 356.

1 Il volume contiene gli atti del $35^{\circ}$ congresso annuale della North American Society for Seventeenth-Century French Literature, tenutosi nel maggio del 2003 al Dartmouth College, specializzato nell'insegnamento e nello studio della lingua e letteratura francese.

2 Il tema del congresso, scelto per esplorare ed indagare la cultura classica francese, prevede il superamento dei tradizionali confini temporali, di genere e di disciplina, grazie ad un approccio interdisciplinare. Durante il congresso, otto sessioni hanno permesso ai partecipanti, per lo più americani, ma anche inglesi, canadesi e francesi, di scoprire le 'intersezioni' fra generi, periodi e discipline che vengono analizzate per lo più separatamente.

3 Il volume si apre con la comunicazione Molière and the Novel di R. GOODKIN, un'introduzione alla prima sessione di «Intersections», Novel and Theater, che, come si 
evince dal titolo, mette in relazione il teatro francese del xvII secolo con il romanzo dello stesso periodo, grazie ai contributi di P. GETHNER, Toward the Classical Unities: How Mairet Adapted d'Urfé for the Stage, di T. P. FINN, Tragedy in the Histoire Comique de Francion, di J. vos-CAMY, Theatrical Intersections in the Novel: Scarron's Roman Comique, di J. CAMPELL, Restoration or Destruction? La Princesse de Clèves Seen through Nathaniel Lee's Adaptation.

a seconda sezione, «Comedy and Tragedy», dedicata a Ronald Tobin, esplora i concetti di commedia e tragedia nel teatro secentesco. Quattro i contributi presenti: Over the Top: From the Tragic to the Comic in Corneille di N. EKSTEIN; Attila (1667): Fathers and Huns di S. R. BAKER; "Quand nous serons à dix, nous ferons une croix": Molière's L'Etourdi or the Secret Life of a Master Fencer di E. Woodrough; Sacred Space and Ironic Polarities in Athalie di R. ALBANESE.

5 La terza sezione, «Print and Performance», mette in relazione due concetti opposti: la pubblicazione, che preserva il testo invariato nel tempo, e la rappresentazione, in cui un gruppo di persone - attori e spettatori - condividono un'esperienza unica quanto effimera. Le comunicazioni appartenenti a questo gruppo sono: Textual Performance: Imprinting the Criminal Body di K. DAUGE-ROTH; Tragic Violence in Performance and Print Illustration: From Monléon's Thyeste to Corneille and Racine di L.F. NORMAN; Performing Print, Forming Print: Montpensier and the Politics of Elite Textual Production di J. CHERBULIEZ; Bearing Witness to the Light: Descartes and Vermeer di H. STONE.

6 La quarta sezione, «Arts and Literature», è dedicata ad una delle 'intersezioni' più esplorate, quella tra la letteratura e l'arte. A questo complesso e fruttuoso rapporto sono dedicati i contributi di L. GAUdIN, Peindre en France au XVII siècle: Un mot, deux arts, une praxis; di S. GENIEYS-KIRK, Le nu féminin dans la Clélie de Madeleine de Scudéry; di G. COWART, La Fontaine on Opera: Musical Commentary as Political Critique.

7 La quinta sezione, «Geographical Spaces», mette in relazione la scrittura con gli spazi geografici, grazie ai contributi di M.C. PIOFFET sulla Cina nelle lettere francesi secentesche (L'Empire du Milieu dans la fiction narrative du XVII siècle); di S. A SHAPIRO sugli spazi geografici nei Mémoires di Mlle de Montpensier (The Fall of the House of Montpensier and the Rise of Richelieu: Geographical Representation in Mademoiselle de Montpensier's Mémoires); di E. M. MCCLURE (Lieu Tenant: Diplomacy and Dementia in Racine's Andromaque) e di L. K. HoRowITZ (East/West: Mapping Racine) su Racine.

8 La sesta sezione, «Human Spaces», contiene tre saggi incentrati sui comportamenti ritenuti deviati nel XVII secolo: sessuali, nel contributo di L.C. SEIFERT, Boisrobert's Cabinet and the Seventeenth-Century Closet; religiosi nel saggio di H. GOLDWYN, Les espaces du Désert ou "les pierres mêmes crieront"; aristocratici nel contributo di A. BIRBERICK, Changing Places: d'Aulnoy's Le Nouveau gentilhomme bourgeois.

9 La settima sezione, «High and Low Culture», si occupa di testi in cui l'alta e la bassa cultura si intersecano e si completano vicendevolmente: L'Astrologie à la croisée des cultures: l'exemple de Molière di Ran-E HONG; Going Through the Trash: Meaning in the Cabaret and Cabinet Baroque Lyric di R. GANIM; The Contes Merveilleux: Point(s) of Contact between Two Cultures di H. NEEMAN.

10 L'argomento dell'ultima sezione, «Sacred and Secular», ben si applica ad un secolo definito contemporaneamente l'età della ragione e l'età del fato. I due concetti non solo coesistono nel XVII secolo, ma sono profondamente collegati a livello politico, sociologico e psicologico. I contributi illustrano questa coesistenza negli scritti di tre 
grandi rappresentanti del Seicento: Pascal (Sacred/Secular Rhetoric in Pascal's Lettres provinciales di E. R. косн); Fénelon (Entre cité terrestre et cité céleste: la machine de Télémaque di J.V. BLANCHARD); M.me d'Aulnoy (Sacre Writings, Secular Identities: d'Aulnoy's Manipulation of the Psalm-Paraphrase Tradition di A. STEDMAN). 